\title{
DIFFERENCES IN NUTRITIONAL STATUS OF PRESCHOOL CHILDREN IN THE CONTEXT OF THE MATERNAL SOCIAL CHARACTERISTICS
}

\author{
ADRIANNA POTOCKA and ALEKSANDRA JACUKOWICZ \\ Nofer Institute of Occupational Medicine, Łódź, Poland \\ Department of Health and Work Psychology
}

\begin{abstract}
Objectives: It is generally accepted that maternal factors are important in maintaining the adequate nutritional status of young children. This study was aimed at verifying whether mother's socio-demographic (age and relationship status) and socio-economic features (education and professional status) differentiate the child's nutritional status. Material and Methods: A cross-sectional study was conducted between April and October 2013. Five hundred thirty mothers of preschool children from 5 different regions of Poland were interviewed. Mothers were interviewed on their socio-demographic and socio-economic status. To assess the child's nutritional status, body mass index (BMI) z-score and the diet indicators were calculated, such as the percentage of the estimated average requirement for energy (\%EAR), the percentage of energy coming from carbohydrates $(\% \mathrm{EC})$, fat $(\% \mathrm{ET})$ and proteins $(\% \mathrm{EP})$. Percentage of the estimated average requirement for energy, \%EC, \%ET and \%EP was obtained from 24-h dietary recalls conducted with the mothers. Results: The results showed that mother's education and professional status did not differentiate any of the indices of the child's nutritional status. However, maternal age and her relationship status occurred significant (ANOVA; $p<0.05$ ). Children of younger mothers had higher BMI z-score and higher \%EC as compared to children of older mothers. Moreover, \%EAR was higher among children of single mothers and it was closer to the recommended nutrition standards as compared to children of mothers with a partner. Conclusions: When a child is diagnosed with any type of malnutrition, it is worth assessing various factors that might influence the nutritional status, such as child's social background (e.g., maternal factors). Int J Occup Med Environ Health 2017;30(5):811-821
\end{abstract}

Key words:

Nutritional status, Diet, Mothers, Body mass, Preschoolers, Social factors

\section{INTRODUCTION}

Proper nutritional status in the early childhood enables the achievement of genetically-determined growth potential and intelligence. Children aged 1-5 years old are especially exposed to disorders related to physical growth, motor and cognitive skills as a result of malnutrition. Diet is particularly important during pregnancy and in the early childhood of a newborn child. This period is crucial for the brain development and, as a consequence, child's cognitive, psychomotor and socio-emotional skills in future life [1].

Protein-energy malnutrition, level of fatty acids, iron, iodine (and thyroid hormones), zinc, choline, B-vitamins have impact on the pivotal neurodevelopment processes

Funding: IMP 21.3. project "Relationship between maternal attitudes and child-feeding practices: importance of attachment style, eating competence and beliefs about combining work and family responsibilities." Project manager: Adrianna Potocka, M.A.

Received: March 18, 2016. Accepted: September 22, 2016.

Corresponding author: A. Potocka, Nofer Institute of Occupational Medicine, Department of Health and Work Psychology, św. Teresy 8, 91-348 Łódź, Poland (e-mail: potocka@imp.lodz.pl). 
such as neuron proliferation, development of axons and dendrites, formation, pruning and functioning of synapsis, as well as myelination and neuronal apoptosis [1]. Nutritional status may influence brain development directly and indirectly. Nutrients deficiencies have a direct impact on the neurodevelopment processes. Malnutrition indirectly influences child's behavior, curiosity and willingness to learn new things - which, in turn, determines further brain development [1].

Studies suggest that malnutrition may cause even a 15-point reduction in child's intelligence quotient (IQ) [2]. Young people are highly sensitive to even minor dietary mistakes and prone to suffer from psychomotor development disorders. Moreover, young age is the moment when people shape their eating habits and their consequences might be experienced for the rest of their lives [3]. Deficiency or excess of nutrients in the diet result in the imbalanced homeostasis of metabolic processes [4,5]. Both, quantitative and qualitative deficiency might deteriorate health, impair the functioning of immune system, reduce the efficiency of respiratory system, disturb the development of bone tissue, increase irritability and decrease attention. As a result, it might lead to worse school achievements [4].

Excessive intake of food in children and young people leads to the development of overweight and obesity. These, in turn, induce disorders in functioning of many body organs or psychosocial problems (low self-esteem, anxiety, depression, eating disorders, social isolation, worse learning results). Inadequate nutritional status refers to all kinds of deviations - including undernutrition as well as overnutrition $[6,7]$.

The former describes low body mass and/or insufficient intake of microelements, the latter describes high body mass and/or excessive intake of microelements. According to the World Health Organization's (WHO) data [8], $39 \%$ people aged over 18 years old all over the world were overweight, and $13 \%$ of them were obese in 2014 . There is also a dramatic increase in the number of overweight children aged under 5 years old. Data provided by the United Nations International Children's Emergency Fund (UNICEF), WHO and World Bank shows that from the year 2000 to 2013 the number of overweight children increased from 32 to 42 million [9].

It is estimated that if this trend continues, the percentage share of overweight children worldwide (aged $<5$ years old) will increase from $7 \%$ in 2012 to $11 \%$ in 2025 [10]. At the same time, statistics indicate that at least a half of children aged between 6 months and 5 years old worldwide suffer from one or more microelements deficiencies [11].

Populations in their developmental age - infants, children and teenagers - are considered to be especially exposed to the increased risk of nutrition disorders [3]. Thus, the assessment of nutritional status is of crucial importance for children. The assessment of nutritional status includes anthropometric indicators (e.g., body mass index - BMI) as well as the indicators of diet (e.g., 24-h dietary recall, food frequency questionnaires or other methods) [12].

In the case of young children, it is the mother who has the greatest influence on their nutritional status [13,14]. The child's nutritional status results from the mother's eating practises and patterns, which, in turn, stem from her economic, cultural, social and individual factors. Social factors refer to the mother's socio-economic and socio-demographic features. Education, income or professional status indicate the socio-economic status (SES) of a particular person [15-17].

It is widely acknowledged that the higher the SES, the healthier the lifestyle, including diet [15,18-20]. People of higher SES have already been confirmed to eat wholemeal products, lean meat, fish, low-fat diary, fresh vegetables and fruit more frequently [19]. Chinese studies have shown the positive relationship between the level of the consumed fat and salt and the level of education higher level of education related to the recommended consumption of these products [21]. 
Fernández-Alvira et al. [22] assessed the relationship between the parents' level of education and the frequency of their children eating products crucial for the development of obesity. The researchers observed a lower consumption of low-sugar and low-fat products (vegetables, fruit, pasta, rice, whole meal bread) and higher consumption of "risky" products (sweetened or salted snacks) in the case of children of parents with lower and medium education (as opposed to the children of parents with higher education). Other research revealed the positive relationship between the parents' education and the child's diet compliant with the recommended nutritional norms [23].

Professional status (employed/unemployed, type of work, occupation) is also considered to influence nutritional status. Previous research suggests that unemployment relates to the increased risk of health disorders. Risk factors such as smoking, lack of physical activity, overweight/ obesity or unhealthy eating habits are more common among the unemployed [15,24,25]. Research including preschool children has revealed that children of unemployed mothers have significantly higher weight-for-height ratio ("wasting") as compared to the children of employed mothers [26].

On the other hand, in many societies it is recognized as better for a child when his or her mother stays at home (especially in the case of young children) rather than when the mother works. Working mothers inevitably have less time for childcare as well as for the nutrition of the family, which is considered as a risk having negative impact on the quality of the children's diet and as a result - their nutritional status [27,28]. However, some research does not confirm the relationship between the mother's professional activity and the child's unhealthy diet [23,29].

Apart from SES (education, income, professional situation), nutritional status is also influenced by the person's socio-demographic status (SDS) [15]. Exemplary indicators of SDS include gender, age and relationship status. Women are generally believed to have higher health awareness, which fosters healthier lifestyle, including healthier diet [27,30-32]. On the other hand, the Lithuanian study has shown that girls have the habit of eating first breakfast at home less frequently than boys [33]. Such outcome might result from the analysis of gender differences among children (aged 7-8 years old), not among adults. Researchers generally agree that age is a strong predictor of health behavior. It is well-acknowledged that the older the person, the healthier his or her lifestyle [15]. The differences in the nourishment and the nutritional status depending on the respondent's age have been confirmed in the Japanese research - employees aged below 30 years old have been noted to consume fewer calories from saturated fatty acids and less calcium, potassium and vitamins $\mathrm{A}$ and $\mathrm{B} 1$ as compared to the workers aged 30 and more years old [34]. Longitudinal studies conducted by Camara et al. [23] have revealed the relationship between mother's age and child's diet at the age of 2, 3 and 5 years old. Younger mother's age has been related to less healthy patterns of feeding children (processed products or fast food).

Mother's young age is considered to have negative impact on the quality of the child's diet. Yet, little is known on the impact of the mother's relationship status on the quality of child's diet [23]. The results achieved by Camara et al. [23] have shown that the mother's relationship status (single or with a partner) does not influence the way of feeding a child. In contrast, some research underlines the relationship between the health status and relationship status - being single relates to more unhealthy behavior [15,29,35-37]. Research including pregnant women has shown that single mothers living with their parents consumed less fruit, vegetables and fiber and their diet contained more calories as compared to the reference group (married/with a partner).

Moreover, single expectant mothers living on their own consumed more refined sugar as compared to the reference group [36]. The daughters of single mothers also had higher BMI, consumed more sweetened drinks and 
showed restrictive patterns of eating more frequently than the girls from full families [35].

Considering social characteristics such as education or age of the mother, research results are rather consistent and show that these variables are significant for the child's nutritional status. In the case of professional and relationship status of the mother, the studies seem to provide conflicting results. Thus, we have aimed at determining which social characteristics of Polish mothers of preschool children relate to the development of disorders in the case of the children's state of nutrition. To attain this objective, we tested the following research questions:

1. $Q_{1}$ : Does maternal socio-economic status (education and professional status) differentiate the body weight and the structure of child's diet?

2. $\mathrm{Q}_{2}$ : Does maternal socio-demographic status (age and relationship status) differentiate the body weight and the structure of the child's diet?

\section{MATERIAL AND METHODS}

\section{Procedure and participants}

The study was conducted between April and October 2013. We included a group of 530 mothers of preschool children (aged 3-5 years old). The women were recruited in 5 regions of Poland - central, western, eastern, northern and southern - each represented by one voivodeship. Two pediatric clinics were randomly selected in each region one from urban and one from rural borough. To exclude any significant influence of the third parties engaged in the child's diet, we set the following inclusion criteria:

- child's grandparents did not live in the same household as the mother and her child/children did,

- mother's control over the child's diet when the child stayed at home was assessed by the mother as higher than $70 \%$,

- if a child did not attend kindergarten, the child was taken care of by a relative or babysitter for shorter than $2 \mathrm{~h}$ a day.
First, 130 respondents were excluded due to considerable missing data. Thus, the statistical analyses were performed including a group of 400 women, 80 respondents from each region - including 40 from urban and 40 from rural areas (in total, 200 respondents from urban and 200 from rural areas). The cohort included $27.5 \%(\mathrm{~N}=110)$ mothers of 3-year-olds, $36.5 \%$ $(\mathrm{N}=146)$ mothers of 4-year-olds and $36 \%(\mathrm{~N}=144)$ of 5-year-olds. Thinness was observed for $10 \%(\mathrm{~N}=11)$ of 3-year-olds, $15.1 \%(\mathrm{~N}=11)$ of 4-year-olds and $6.2 \%$ $(\mathrm{N}=9)$ of 5-year-olds. In the group of 3-year-old children, $9.1 \%(\mathrm{~N}=10)$ were overweight and $8.2 \%(\mathrm{~N}=9)$ were obese; among 4-year-olds 7.5\% ( $\mathrm{N}=11)$ were overweight and $10.3 \%(\mathrm{~N}=15)$ were obese; in the group of 5-year-old children $18.0 \%(\mathrm{~N}=26)$ were overweight and $5.5 \%(\mathrm{~N}=8)$ were obese.

The mean age of mothers equaled 30.4 (standard deviation $-\mathrm{SD}=4.35), 51.5 \%(\mathrm{~N}=206)$ women were aged 29 years old or below, $48.5 \%(\mathrm{~N}=194)$ respondents were aged 30 years old or above. The majority of the studied mothers declared to have a life partner/husband $-85.8 \%(\mathrm{~N}=343), 14.3 \%(\mathrm{~N}=57)$ mothers described themselves as "singles." Women with secondary $(\mathrm{N}=172)$ and bachelor education $(\mathrm{N}=93)$ dominated in the sample (43\% and $23.5 \%$, respectively); vocational education was declared by $18.5 \%(\mathrm{~N}=74)$ respondents, master's degree $-12.8 \%(\mathrm{~N}=51)$ and primary education $-2.5 \%(\mathrm{~N}=10)$ women. Considering the professional status, full time workers constituted the largest group in the sample $-60.5 \%(\mathrm{~N}=242)$, followed by women working part-time $-31 \%(\mathrm{~N}=124)$ and women on parental leaves $-8.5 \%(\mathrm{~N}=34)$.

\section{Measures}

To measure the variables, a standardized individual survey was used, including socio-demographic survey and 24-h diet diary recall. The socio-demographic survey: 
a) Mother's socio-demographic status:

- age - based on the age declared by the studied mothers, we divided the participants into 2 age groups: mothers aged $\leq 29$ or mothers aged $\geq 30$;

- relationship status - single mothers or mothers having life partners/husbands.

b) Mother's socio-economic status:

- education - primary, vocational, secondary, bachelor or master's degree;

- professional status - mothers working full time, parttime or mothers on parental leaves.

c) Anthropometric and social features of a child:

-age,

- height,

- current body weight.

The nutritional status was assessed by means of the World Health Organization body mass index (BMI) z-score for age (based on the data declared by mothers). Reference values for 3-year-olds: $15.5 \mathrm{~kg} / \mathrm{m}^{2} \pm \mathrm{SD}$, for 4-year-olds and 5-year-olds: $15.3 \mathrm{~kg} / \mathrm{m}^{2} \pm \mathrm{SD}$.

Twenty-four-hour diet diary recall - one interview conducted with a mother by a trained interviewer; it allowed to assess the child's diet; included the data on the amount and type of food consumed by a child during a day preceding the study. The standard portion sizes were estimated with the use of the album of food photographs developed by the National Food and Nutrition Institute [38]. All of this data served to assess the indices of the diet's structure: a) \%EAR - percentage of the realization of the estimated average requirement for energy; for children aged 3 years old EAR $=1000 \mathrm{kcal} /$ day, for 4-5-yearolds $\mathrm{EAR}=1400 \mathrm{kcal} / \mathrm{day} ; \mathrm{b}) \% \mathrm{EC}, \% \mathrm{EF}, \% \mathrm{EP}-$ the percentage share of energy coming from nutrients (EC - energy from carbohydrates, EF - energy from fat, EP - energy from proteins) assessed on the basis of the analysis of the child's diet. Reference to the nutrition recommendations: $\% \mathrm{EC}=50-55 \%, \% \mathrm{EF}=30-35 \%$, $\%$ EP $=10-12 \%$.

\section{Statistics}

The analyses were conducted with the use of statistical package Statistica 10 and the program to assess the indices of the diet's structure (Dieta5, published by the Polish National Food and Nutrition Institute). To answer the questions, a one-way analysis of variance ANOVA was conducted (level of significance $\mathrm{p}<0.05$ ).

\section{RESULTS}

\section{Testing $Q_{1}$ : Does maternal socio-economic status (education and professional status) differentiate the body weight and the structure of child's diet?}

The results suggest the mother's education does not differentiate either the child's BMI $(\mathrm{F}(4.395)=$ $1.433, \mathrm{p}>0.05)$ or any of the indices of the child's nutrition: \%EAR $(\mathrm{F}(4.395)=0.056, \mathrm{p}>0.05)$, $\% \mathrm{EC}(\mathrm{F}(4.395)=1.359, \mathrm{p}>0.05), \% \mathrm{EF}(\mathrm{F}(4.395)=$ 2.091, $\mathrm{p}>0.05)$ and \% $\mathrm{EP}(\mathrm{F}(4.395)=1.605$, $\mathrm{p}>0.05)$.

Further, there were no differences in child's nutritional status between the children of working mothers (fulltime or part-time) and mothers on parental leaves: BMI $(\mathrm{F}(2.397)=0.768, \mathrm{p}>0.05), \% \operatorname{EAR}(\mathrm{F}(2.397)=$ 1.071, $\mathrm{p}>0.05), \% \mathrm{EC}(\mathrm{F}(2.397)=2.40, \mathrm{p}>0.05)$, $\% \mathrm{EF}(\mathrm{F}(2.397)=1.207, \mathrm{p}>0.05)$ and \% $\mathrm{EP}(\mathrm{F}(2.397)=$ $1.708, \mathrm{p}>0.05)$.

\section{Testing $Q_{2}$ : Does maternal socio-demographic status (age and relationship status) differentiate the body weight and the structure of the child's diet?}

The analysis of the differences in the child's nutritional status depending on the mother's age was based on the division of the mothers into a group of younger (aged 29 years old or below) and older mothers (aged 30 years old or above). The analysis of variance showed significant differences in BMI of children of younger mothers as compared to children of older mothers $(\mathrm{F}(1.398)=15.36$, $\mathrm{p}<0.05)$. Post hoc comparisons $(\mathrm{p}<0.001)$ suggest 


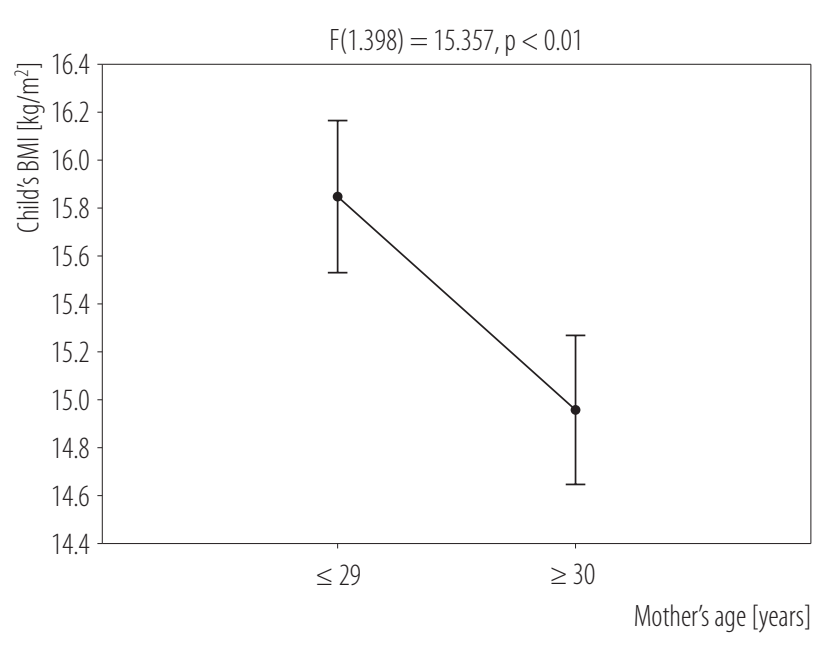

Fig. 1. Differences in child's body mass index (BMI) depending on the mother's age in the study of mothers $(\mathrm{N}=400)$ of preschool children, Poland, 2013 - analysis of variance (ANOVA)

that BMI of younger mothers' children were significantly higher $\left(15.86 \mathrm{~kg} / \mathrm{m}^{2}\right)$ than those of children of older mothers $\left(14.97 \mathrm{~kg} / \mathrm{m}^{2}\right)$ (Figure 1).

\section{Age}

Age occurred to be one of the significant sources of variance of the percentage share of energy coming from carbohydrates $(F(1.398)=3.83, p=0.051)$. Percentage of the estimated average requirement for energy in the diet of younger mothers' children was higher $(57.02 \%)$ as compared to the $\% \mathrm{EC}$ in the diet of children of older mothers (55.49\%) (post hoc comparisons) (Figure 2). No significant differences in the other indices of child's nutrition were observed: $\% \operatorname{EAR}(\mathrm{F}(1.398)=3.83, \mathrm{p}>0.05), \% \mathrm{EF}(\mathrm{F}(1.398)=2.592$, $\mathrm{p}>0.05)$ and $\% \mathrm{EP}(\mathrm{F}(1.398)=0.842, \mathrm{p}>0.05)$.

Mother's relationship status was assumed as another potential source of variance in the indices of child's nutritional status. We assumed that BMI, \%EAR, \%EC, \%EF and \% EP might have varied between the children of single mothers and mothers having life partners/husbands. It occurred that the mother's relationship status had no significant influence on the child's BMI $(\mathrm{F}(1.398)=0.064, \mathrm{p}>0.05)$,

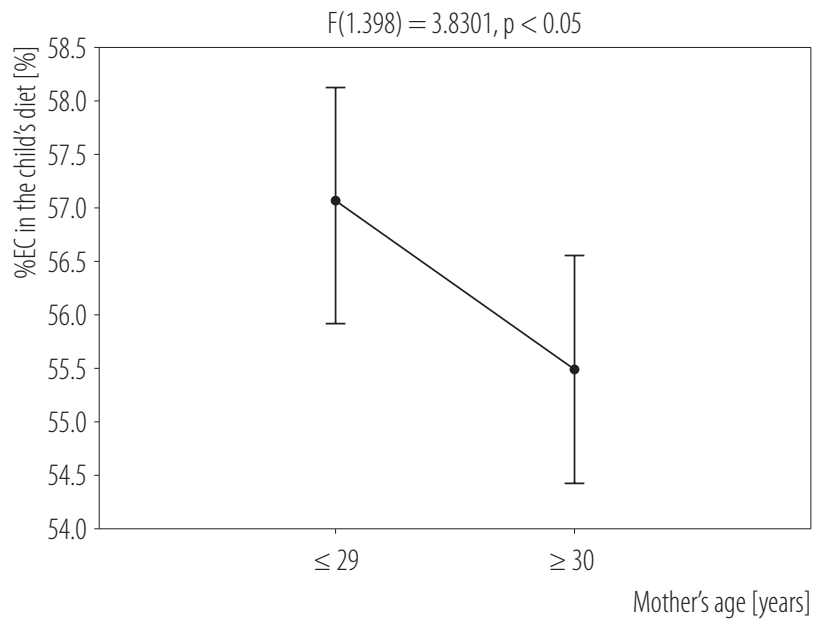

Fig. 2. Differences in percentage of the estimated average requirement for energy (\%EC) (percentage share of energy coming from carbohydrates) in the child's diet depending on the mothers' age in the study of mothers $(\mathrm{N}=400)$ of preschool children, Poland, 2013 - analysis of variance (ANOVA)

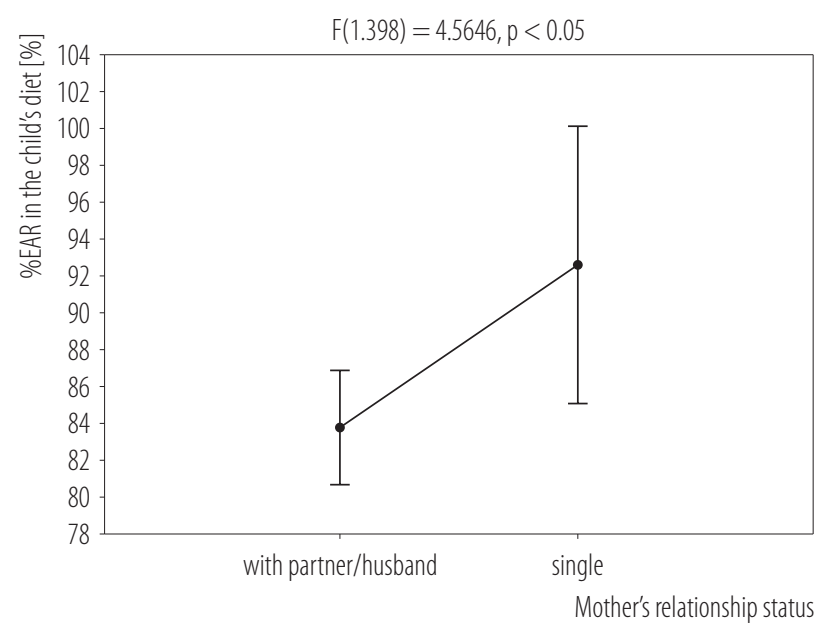

Fig. 3. Differences in percentage of the realized estimated average requirement for energy (\%EAR) in the child's diet depending on the mothers' relationship status in the study of mothers $(\mathrm{N}=400)$ of preschool children, Poland, 2013 analysis of variance (ANOVA)

$\% \mathrm{EC}(\mathrm{F}(1.398)=1.27, \mathrm{p}>0.05), \% \mathrm{EF}(\mathrm{F}(1.398)=1.533$, $\mathrm{p}>0.05)$ or $\% \mathrm{EP}(\mathrm{F}(1.398)=0.028, \mathrm{p}>0.05)$.

However, we observed significant differences depending on the mother's relationship status in the percentage share of the realization of the estimated average 
requirement for energy (\%EAR) for a particular child's age group $(\mathrm{F}(1.398)=4.565, \mathrm{p}<0.05)$. Percentage of the estimated average requirement for energy (\%EAR) was higher for single mothers' children (92.59\%) than in the group of children of mothers declaring to have life partners/husbands $(83.80 \%)$ (post hoc comparisons, $\mathrm{p}<0.05$ ) (Figure 3).

\section{DISCUSSION}

This paper presents the results on the differences in the child's nutritional status (BMI, \% EAR, \%EC, \%EF, \%EP) considering selected social features of mothers (education, professional status, age and personal status). The results showed that mother's education and professional status did not differentiate any of the indices of the child's nutritional status. However, maternal age and her relationship status occurred significant. Children of younger mothers had higher BMI z-score and higher \%EC as compared to children of older mothers. Moreover, \%EAR was higher among children of single mothers and it was closer to the recommended nutrition standards as compared to children of mothers with a partner.

In this study, neither mother's education nor her professional status occurred significant for any of the analyzed indices of the child's nutritional status. Our result on the lack of relation of education with the nutritional status seems surprising since the level of education is commonly considered as a strong predictor of health behavior.

Such result was confirmed by a French research including adults aged 35-64 - it showed that higher education related to the positive attitude towards healthy food and the choice of healthier products [16]. It was also revealed that children of the better-educated mothers consumed more portions of fruit and vegetables during the day and ate breakfasts more often that the children of lower-educated mothers did [39].

Lack of the differences of the effect of education might result from the prevailing trend in Poland encouraging to eat and cook healthy. Thus, mothers have access to many sources of information on child's proper nutrition (massmedia, doctors, kindergartens, etc.). Moreover, the age of a child imposes a particular way of feeding a child - young children's diet is less varied than that of teenagers or adults. Similarities in the way parents (or institutions such as nurseries or kindergartens) compose the young children's diet result from the products dedicated especially to children available in the market (e.g., cereals, milk products, juice, drinks, sweetened snacks of particular brands) that are particularly promoted by advertisements. Moreover, children clearly prefer particular products and dishes (e.g., sausages, white rolls, pancakes, French fries, juice, sweets) that parents willingly include in the child's diet because it makes them sure their child will eat them.

Thus, young children's diet might be dependent on the availability of particular products and commonly known patterns of eating (e.g., milk and cereals for breakfast, sandwich and fruit for lunch, two-course dinner, etc.) to a greater extent than it depends on other variables, such as parents' education or professional status.

Some studies suggest that having mother at home is more beneficial for the nutrition of young children (including preschool children) [28,29,40]. For instance, Li et al. [27] show that the fact of mothers staying with their children in their early and later childhood relates to a better quality of a diet in their teenage life. Full concentration on a child allows to control the child's development and factors that might potentially influence it - including a diet. It might be expected then that the nutritional status of children of mothers working full-time should differ significantly in comparison to the children whose mothers work. Research in this area provides various results - some suggest that the diet of children of working mothers is less healthy in comparison with the diet of children of nonworking mothers $[27,40]$ whereas others do not confirm such conclusions [23,29]. 
Our results correspond to the last group of studies - they show no relation between the mother's professional status and any of the analyzed indices of the child's nutritional status. Lack of differences might be explained with the characteristics of the studied respondents - the diet of children staying at home with their mother is similar to the way of feeding children in kindergartens (child's age imposes the certain diet).

However, we have not analyzed the number of children who attended kindergartens even though their mothers did not work. The economic situation in the households might also have impact on the relation between the mother's professional status and the child's nutritional status. For instance, if the woman's income considerably increases the standard of living in a particular household, it might be expected that her professional status will have a greater influence for the mother's activity as regards diet, and health in general.

Negash et al. [41] showed that it was the mother's income that occurred to be a strong predictor of the analyzed indices of children's nutritional status. Thus, it seems reasonable to consider the income in the household - especially the mother's contribution - in the analysis of the relation between the child's diet and the mother-related factors.

Some studies [23,41], but not all [42], indicate mother's younger age as a risk factor for the development of disorders in the child's nutritional status. In our study we revealed differences in BMI and the percentage share of energy coming from carbohydrates depending on the mother's age. Body mass index of children of younger mothers was significantly higher than that of children of older mothers. Yet, both values $( \pm 2 \mathrm{SD})$ remained within the limits set by the norms for 3-year-olds and 4-5-year-olds. Higher BMI for younger mothers' children might result from the higher percentage share of energy coming from carbohydrates (\%EC) for these children $(57.02 \%)$ as compared to \% EC for children of older mothers $(55.49 \%)$.
The analysis of data from 24-h diet diary recalls has shown a significant $(\mathrm{p}<0.05)$, yet weak correlation between the child's BMI and the content of carbohydrate (Pearson's $r=0.16$ ) and sucrose (Pearson's $r=0.14$ ) in their diet. Thus, it may be concluded that the mother's younger age relates to a children's higher BMI and higher \%EC in their diet and thus, to a greater risk of disorders related to overnutrition as compared to older mothers.

Similarly to Ickes et al. [43] and Rondo et al. [44] we have not confirmed the relationship between the mother's relationship status and the anthropometric indicator (child's BMI). However, in contrast to other studies $[23,45,46]$, we have observed significant differences in the assessment of the child's diet depending on the mother's relationship status. It has turned out that the percentage share of the realization of the average requirement for energy (\%EAR) among single mother's children has been closer to that recommended in the nutrition norms $(92.59 \%)$ than the diet of children of mothers declaring to have life partners/husbands $(83.80 \%)$.

\section{Limitations}

The cross-sectional nature of this study limits the possibility to interpret the results. The outcomes cannot be generalized as they only refer to Polish mothers of preschool children. We are also aware of many other mother-related factors that could possibly shape the children's nutritional status and have not been considered in this study.

However, the presented results constitute a part of a larger study - currently we are conducting analyses including other characteristics of mothers (including cultural and psychological features), having an important impact on the children's nutritional status. We hope that expanding the analysis with additional factors will allow for better understanding of the relationships between the mother factors and the child's nutritional status and thus, prevent the negative consequences of improper nutrition among Polish children. 


\section{CONCLUSIONS}

Mother's level of education and professional status do not influence the child's nutritional status.

Mother's age and relationship status constitute significant sources of variance of some indices of child's nutritional status.

In this study, we have found no significant relationships between the mother's socio-economic status and the child's nutritional status. However, we have revealed the associations between the mother's age and the children's BMI and the percentage share of energy coming from carbohydrates in the child's diet. We have also shown the differences between the percentage of the realization of the estimated average requirement for energy in the diet of children of single mothers and mothers having partners/husbands.

When a child is diagnosed with any type of malnutrition, it is worth assessing various factors that might influence the nutritional status, such as child's social background (e.g., maternal age, parental education and their hours of working, siblings, income). It would provide an additional area for research on the reasons of potential disorders as regards children's nutritional status.

\section{REFERENCES}

1. Prado EL, Dewey KG. Nutrition and brain development in early life. Nutr Rev. 2014;72(4):267-84, https://doi.org/ 10.1111/nure.12102.

2. Waristo O, Khomsan A, Hernawati N, Anwar F. Relationship between nutritional status, psychosocial stimulation and cognitive development in preschool children in Indonesia. Nutr Res Pract. 2012;6(5):451-7, https://doi.org/10.4162/ nrp.2012.6.5.451.

3. Wądołowska L. [Groups of populations at increased risk of health disorders and their nutrition problems]. In: Gawęcki J, Roszkowski W, editors. [Human nutrition and public health]. Warszawa: Polskie Wydawnictwo Naukowe; 2009. p. 219-38. Polish.
4. Charzewska J, Wajszczyk B. [What should a proper and balanced diet contain? The role of diversified diet]. In: Jarosz M, editor. [Principles of proper nutrition of children and teenagers and tips on healthy lifestyle]. Warszawa: National Food and Nutrition Institute; 2008. p. 29-43. Polish.

5. Kondrup J. [Energy and protein balance]. In: Sobotka L, editor. [Basics in clinical nutrition]. Warszawa: Wydawnictwo PZWL; 2008. p. 1-5. Polish.

6. Food And Agriculture Organization of the United Nations. Evaluation of FAO's role and work in nutrition. Rome: The Organization; 2011.

7. Food And Agriculture Organization of the United Nations. The state of food and agriculture. Food systems for better nutrition. Rome: The Organization; 2013.

8. World Health Organization [Internet]. Geneva: The Organization; 2017 [cited 2015 Nov 17]. Obesity and overweight. Available form: http://www.who.int/mediacentre/factsheets/ fs311/en.

9. World Health Organization [Internet]. Geneva: The Organization; 2017 [cited 2015 Oct 20]. Global Database on Child Growth and Malnutrition. 2013 Joint child malnutrition estimates - Levels and trends. Available from: http://www.who. int/nutgrowthdb/estimates2013/en.

10. World Health Organization. Global nutrition targets 2025: Childhood overweight. Policy brief. Geneva: The Organization; 2014.

11. Micronutrient Initiative. Investing in the Future: A united call to action on vitamin and mineral deficiencies. Global report 2009. Ottawa: The Initiative; 2009.

12. Pitea MA, Baghiu DM, Mărginean O, Eşianu A. Nutritional status assesment in overweight and obese children. Acta Med Marisiensis. 2012;58(2):116-9.

13. Backman DR, Haddad EH, Lee JW, Johnston PK, Hodgkin GE. Psychosocial predictors of healthful dietary behavior in adolescents. J Nutr Educ Behav. 2002;34(4):184-93, https://doi.org/10.1016/S1499-4046(06)60092-4.

14. Johnson CM, Sharkey JR, McIntosh AW, Dean WR. "I'm the Momma": Using photo-elicitation to understand matrilineal 
influence on family food choice. BMC Womens Health. 2010;10:21-34, https://doi.org/10.1186/1472-6874-10-21.

15. Dorner TE, Stronegger WJ, Hoffmann K, Stein KV, Niederkrotenthaler T. Socio-economic determinants of health behaviours across age groups: Results of a cross-sectional survey. Wien Klin Wochenschr. 2013;125(9-10):261-9, https:// doi.org/10.1007/s00508-013-0360-0.

16. Lê J, Dallongeville J, Wagner A, Arveiler D, Haas B, Cottel D, et al. Attitudes toward healthy eating: A mediator of the educational level-diet relationship. Eur J Clin Nutr. 2013;67(8):808-14, https://doi.org/10.1038/ejcn.2013.110.

17. Vlismas K, Stavrinos V, Panagiotakos DB. Socio-economic status, dietary habits and health-related outcomes in various parts of the world: A review. Cent Eur J Public Health. 2009;17(2):55-63.

18. Sanchez-Villegas A, Martínez JA, Prättälä R, Toledo E, Roos G, Martínez-González MA. A systematic review of socioeconomic differences in food habits in Europe: Consumption of cheese and milk. Eur J Clin Nutr. 2003;57: 917-29, https://doi.org/10.1038/sj.ejcn.1601626.

19. Darmon N, Drewnowski A. Does social class predict diet quality? Am J Clin Nutr. 2008;87(5):1107-17.

20. McGill R, Anwar E, Orton L, Bromley H, Lloyd-Williams F, O'Flaherty M, et al. Are interventions to promote healthy eating equally effective for all? Systematic review of socioeconomic inequalities in impact. BMC Public Health. 2015;15:457, https://doi.org/10.1186/s12889-015-1781-7.

21. Wang Q, Yamashita T, Xu J, Shen JJ, Neishi S, Cheng G, et al. The spouse's level of education and individuals' dietary behaviors in China. Int J Behav Med. 2014;22(4):461-70, https://doi.org/10.1007/s12529-014-9444-0.

22. Fernández-Alvira JM, Mouratidou T, Bammann K, Hebestreit A, Barba G, Sieri S, et al. Parental education and frequency of food consumption in European children: The IDEFICS study. Public Health Nutr. 2013;16(3):487-98, https://doi.org/10.1017/S136898001200290X.

23. Camara S, de Lauzon-Guillain B, Heude B, Charles M-A, Botton J, Plancoulaine S, et al. Multidimensionality of the relationship between social status and dietary patterns in early childhood: Longitudinal results from the French EDEN mother-child cohort. Int J Behav Nutr Phys Act. 2015;12(122), https://doi.org/10.1186/s12966-015-0285-2.

24. Freyer-Adam J, Gaertner B, Tobschall S, John U. Health risk factors and self-rated health among job-seekers. BMC Public Health. 2011;11(1):659, https://doi.org/10.1186/14712458-11-659.

25. Schunck R, Rogge BG. Unemployment and its association with health-relevant actions: Investigating the role of time perspective with German census data. Int J Public Health. 2010;55(4):271-8, https://doi.org/10.1007/s00038-009-0075-1.

26. Shuhaimi F, Muniandy ND. The association of maternal employment status on nutritional status among children in selected kindergartens in Selangor, Malaysia. Asian J Clin Nutr. 2012;4(2):53-66, https://doi.org/10.3923/ajcn. 2012.53.66.

27. Li KK, Concepcion RY, Lee H, Cardinal BJ, Ebbeck V, Woekel E, et al. An examination of sex differences in relation to the eating habits and nutrient intakes of university students. J Nutr Educ Behav. 2012;44(3):246-50, https:// doi.org/10.1016/j.jneb.2010.10.002.

28. Nair M, Ariana P, Webster P. Impact of mothers' employment on infant feeding and care: A qualitative study of the experiences of mothers employed through the Mahatma Gandhi National Rural Employment Guarantee Act. BMJ Open. 2014;4(4):e004434, https://doi.org/10.1136/bmjopen2013-004434.

29. Gwozdz W, Sousa-Poza A, Reisch LA, Ahrens W, Eiben G, Fernandéz-Alvira JM, et al. Maternal employment and childhood obesity - A European perspective. J Health Econ. 2013;32(4):728-42, https://doi.org/10.1016/j.jhealeco. 2013.04.003.

30. Arganini C, Saba A, Comitato R, Virgili F, Turrini A. Gender differences in food choice and dietary intake in modern Western societies. In: Maddock J, editor. Public health - Social and behavioral health. InTech; 2012. p. 83-102, https:// doi.org/10.5772/37886. 
31. Davy SR, Benes BA, Driskell JA. Sex differences in dieting trends, eating habits, and nutrition beliefs of a group of Midwestern college students. J Am Diet Assoc. 2006;106(10): 1673-7, https://doi.org/10.1016/j.jada.2006.07.017.

32. Leblanc V, Bégin C, Corneau L, Dodin S, Lemieux S. Gender differences in dietary intakes: What is the contribution of motivational variables? J Hum Nutr Diet. 2015;28(1):3746, https://doi.org/10.1111/jhn.12213.

33. Petrauskienè A, Žaltauskẻ V, Albavičiūtė E. Family socioeconomic status and nutrition habits of 7-8 year old children: Cross-sectional Lithuanian COSI study. Ital J Pediatr. 2015;41(1):34, https://doi.org/10.1186/s13052-015-0139-1.

34. Morikawa Y, Miura K, Sasaki S, Yoshita K, Yoneyama S, Sakurai M, et al. Evaluation of the effects of shift work on nutrient intake: A cross-sectional study. J Occup Health. 2008;50(3):270-8, https://doi.org/10.1539/joh.L7116.

35. Elfhag K, Rasmussen F. Food consumption, eating behaviour and self-esteem among single v. married and cohabiting mothers and their 12-year-old children. Public Health Nutr. 2008;11(9):934-9, https://doi.org/10.1017/S136898000 8002449.

36. Farbu J, Haugen M, Meltzer HM, Brantsæter AL. Impact of singlehood during pregnancy on dietary intake and birth outcomes - A study in the Norwegian Mother and Child Cohort Study. BMC Pregnancy Childbirth. 2014;14:396, https:// doi.org/10.1186/s12884-014-0396-9.

37. Rousou E, Kouta C, Middleton N, Karanikola M. Single mothers' self-assessment of health: A systematic exploration of the literature. Int Nurs Rev. 2013;60(4):425-34, https:// doi.org/10.1111/inr.12044.

38. Szponar L, Wolnicka K, Rychlik E. [Album of photographs of food products and dishes]. Warszawa: National Food and Nutrition Institute; 2000. Polish.
39. Van Ansem WJ, Schrijvers CT, Rodenburg G, van de Mheen D. Maternal educational level and children's healthy eating behaviour: Role of the home food environment (cross-sectional results from the INPACT study). Int J Behav Nutr Phys Act. 2014;11:113, https://doi.org/10.1186/s12966-014-0113-0.

40. Datar A, Nicosia N, Shier V. Maternal work and children's diet, activity, and obesity. Soc Sci Med. 2014;107:196-204, https://doi.org/10.1016/j.socscimed.2013.12.022.

41. Negash C, Whiting SJ, Henry CJ, Belachew T, Hailemariam TG. Association between maternal and child nutritional status in Hula, rural Southern Ethiopia: A cross sectional study. PLoS One. 2015;10(11):e0142301, https://doi. org/10.1371/journal.pone.0142301.

42. Sonkaria L, Zafer A, Gaur K, Manohar RK. Maternal factors associated with nutritional status of 1-5 years children residing in field practice area of rural health training centre. Natl J Community Med. 2014;5(3):283-7.

43. Ickes SB, Hurst TE, Flax VL. Maternal literacy, facility birth, and education are positively associated with better infant and young child feeding practices and nutritional status among Ugandan children. J Nutr. 2015;145(11):2578-86, https://doi.org/10.3945/jn.115.214346.

44. Rondo PHC, Rezende G, Lemos JO, Pereira JA. Maternal stress and distress and child nutritional status. Eur J Clin Nutr. 2013;67:348-52, https://doi.org/10.1038/ejcn.2013.28.

45. Fisk CM, Crozier SR, Inskip HM, Godfrey KM, Cooper C, Robinson SM. Influences on the quality of young children's diets: The importance of maternal food choices. Br J Nutr. 2011;105(2):287-96, https://doi.org/10.1017/S0007114510003302. 46. Nwaru BI, Onyeka IN, Ndiokwelu C, Esangbedo DO, Ngwu EK, Okolo SN. Maternal and child dietary patterns and their determinants in Nigeria. Matern Child Nutr. 2015;11:283-296, https://doi.org/10.1111/mcn.12011.

This work is available in Open Access model and licensed under a Creative Commons Attribution-NonCommercial 3.0 Poland License - http://creativecommons.org/ licenses/by-nc/3.0/pl/deed.en. 